This is an electronic version of an article published in the Norwegian Journal of Geography@ 2004 Copyright Taylor \& Francis; Norwegian Journal of Geography is available online at http://www.informaworld.com

[http://www.informaworld.com/smpp/ftinterface $\sim$ content $=a 713800941 \sim$ fulltext $=71324$ 0928] 


\section{Preferential treatment in a transition economy:}

the case of state-owned enterprises in the textile and garment industry in Vietnam

Published in Norwegian Journal of Geography 2004 vol. 58: 125-135

Hege M. Knutsen, University of Oslo, Norway

h.m.knutsen@sosgeo.uio.no

Cuong Manh Nguyen, National Economics University, Vietnam manhcuongiss@yahoo.com

Department of Sociology and Human Geography University of Oslo

P.O.Box 1096 Blindern

$\mathrm{N}-0317$ OSLO Norway

Telephone: $\quad+4722855257$

Fax: $\quad+4722855253$

Internet: http://www.iss.uio.no 


\title{
Preferential treatment in a transition economy: the case of state-owned enterprises in the textile and garment industry in Vietnam
}

\author{
HEGE MERETE KNUTSEN \& CUONG MANH NGUYEN
}

\section{Introduction}

With the growing influence of neoliberal economics in economic policy and development thinking in the 1980s, the role of state interventionist policies has come under heavy attack. The World Bank recommends and demands privatization of state enterprises both as part of a larger transformation from state socialism to market economy and as part of its Structural Adjustment Programmes. In 1986 Vietnam promulgated doi moi, a process for economic renewal. The economy is in transition from state socialism and central planning to a multisectoral economy guided by market principles (Wolff 1999). The policy involves changes in the management of state enterprises and opens for establishment and growth of a private sector. The process of privatization of state enterprises has been slow and the Government is under pressure to accelerate the process. According to the World Development Report of 1987, the performance of state enterprises in developing countries has been frequently poor and state enterprises have failed to play a strategical role in the process of industrialization (Chang 2003). Zahra \& Hansen $(2000,87)$ claim that 'the globalization of the world economy, the breath-taking technological progress, the SOEs' [state enterprises] dismal record of performance and the explosion of demands for greater accountability have combined to pressure countries to liberalize their economies through privatization'. However, the authors also make a point that 'potential implications of privatization for global competitiveness have not been discussed' (Zahra \& Hansen 2000, 84). Softer critics argue that state enterprises may be managed in such a way that they do not necessarily contribute negatively to industrial growth (Asher 1997, Chang 2003). Vietnam has experienced impressive growth in exports of textiles and garments, from USD 28 million in 1985 to USD 1.8 billion in 2000 and USD 2.7 billion in 2002 (Hill 2000, CIEM 2002, Vietnam News 2003). Exports of textile and garments from Vietnam are only surpassed by exports of crude oil. The textile and garents industry employs c.1.6 million people (Vinatrade USA 2004). The objective of this article is to examine the role and contribution of preferential treatment of state enterprises for growth in the textile and garment industry. The Law on State Enterprises (1995) distinguishes between state enterprises that operate for profit and those that have wider social obligations such as public utilities and national defence (VNC 1995). The textile and garment industry belongs to the former category of 'business for profit'. This raises the following three questions: What is the contribution of the state enterprises to the textile and garment industry in terms of output and exports? To what degree are state enterprises subject to preferential treatment? In what ways does preferential treatment of state enterprises affect their contribution to the growth of the industry? The last question is of particular interest given the notion that privatization is crucial to global competitiveness (Zahra \& Hansen 2000). This also means that it is necessary to examine the role of the state enterprises in Vietnam in the intersection of global competition in the textile and garment industry and the domestic transition context. Preferential treatment occurs in access to land, credit and export quotas. State enterprises refer to enterprises wholly owned by the state and enterprises in which the state controls the voting shares. The concepts of state enterprises and state sector are used interchangeably. The analysis is based on primary quantitative and 
qualitative data combined with national statistics and newspaper reports. The survey data consists of interviews in 96 enterprises, i.e. 58 state enterprises, 25 private Vietnamese enterprises and 13 foreign enterprises, in the period 1997-1998. The response rate was 80\%. This is acceptable taking into consideration general problems of data collection in Vietnam, but there is likely to be an overrepresentation of firms that perform well. However, the sample is sufficiently large to compare the three categories of enterprises and gain more systematic and detailed knowledge about the differences between them. Consistency and reliability of the data have been checked. The survey data was supplemented with in-depth interviews with managers and other industry sources in 2000 and 2002.1 The respondents talked about their own enterprise or organization in particular and conditions in the industry in general. National statistics have been questioned in previous studies of the economy: inconsistency between output and export figures have been detected (Hill 1998), and for the period 19901995 Griffin (1998) argues that the output of state enterprises is overestimated. Hence, it is important to note that the national statistics presented below only are rough indicators of some main trends in the development of the textile and garment industry. In the following, a presentation is given of the concept of preferential treatment and theoretical arguments regarding relationships between state ownership, preferential treatment and global competitiveness. A short note on the nature of global competition in the industry and the context of transition in Vietnam precedes the examination of the performance of the textile and garment industry and the significance of the state enterprises in this. Against this backdrop of secondary data, the primary quantitative and qualitative data on the extent, nature and implications of preferential treatment of state enterprises are presented and discussed.

\section{Preferential treatment in a transition economy context}

When the state adopts the role of producer, the objective is more than to generate profits and contribute to government revenue. In addition to control over national defence and vital natural resources, it is a means to secure public utilities in fields that are too risky or not sufficiently remunerating to private enterprises. State enterprises may also be established to produce 'private' goods with the aim of securing employment and reasonably priced products (Waterbury 1993, Chang 2003). Due to the multiple objectives of state enterprises, a soft budget constraint is pervasive in state socialism, although it may occur even in fully privatized economies. A soft budget constraint means that a supporting organization covers all or part of the deficit of the enterprises in question. Loss-making enterprises are not allowed to fail, but are supported and rescued with financial subsidies and other instruments. This contrasts with a hard budget constraint under which enterprises have to cover their expenditures through their initial endowment and revenue (Kornai et al. 2002). In a transition economy, as in the case of Vietnam, a soft budget constraint may be considered a legacy of state socialism. When the soft budget constraint is biased in favour of a particular category or sector of enterprises, the outcome is preferential treatment of such. In addition, enterprises that are not loss making may enjoy preferential treatment as a means to boost their competitiveness in the national or global market. It is necessary to understand preferential treatment not only as something practised in accordance with existing laws and regulations, but that also results from socially sanctioned norms. Norms affect how laws and regulations are implemented in practice and may even result in preferential treatment that has no obvious basis in the legal framework. Socially sanctioned norms are important because the nature of a transition process is 'volatile and uncertain without an adequate legal framework, a stable political structure and functioning strategic factor markets’ (Peng 2000, 53). In the same vein, personalized networks are reinforced during the process of transition because they ensure some constancy and predictability. 


\section{The neoliberal argument and its counter perspectives}

Western neoliberals particularly criticize state enterprises for not being sufficiently efficient and advocate rapid privatization (Ellman 1997). Conflicts between some of the multiple objectives of the state enterprises reduce the focus on profitability. For instance, cheaper and faster production by mechanisation and automation conflicts with the objective of securing employment for a large number of workers. Moreover, managers have limited autonomy and decisions are subject to heavy bureaucracy, especially when the enterprises have obligations that sort under different government departments. Managers may act opportunistically and accountability may be limited when control is dispersed and obligations are not clearly defined. Neoliberal economists advocate privatization of state enterprises because the market mechanisms will expose them to competitive pressure and thus force them to develop new and better products and reduce their cost of production in order to survive in the market. In a context of scarce national resources, preferential treatment of state enterprises leaves less for the potentially more dynamic private sector, either privatized state enterprises or new private enterprises. Not only have state enterprises 'stifled the growth of private enterprises by seeking government protection', the generous loans that they often receive from government officials insulate them from the discipline of the free market (Zahra \& Hansen 2000, 85). Empirical studies reveal that rapid privatization of state enterprises has been less important for attaining economic growth than rapid development of private firms (Johnson \& Loveman 1995, Ellman 1997). The argument is that it is more difficult to restructure, revitalize and privatize state enterprises than to start over with new private enterprises. According to Zahra \& Hansen (2000), an important obstacle to privatization is that the government can no longer promise full employment and layoffs may be counter to national cultures. They also mention that it takes a long time to change institutional and employee mind-sets and that experienced managers are lacking. Their main concern is that privatization can spur entrepreneurship, which in turn is important to competitiveness, but that privatization is difficult to implement. Softer critics of state enterprises argue that state enterprises must be evaluated according to their objectives and are not necessarily less efficient than private enterprises. Sounder control systems of state enterprises can be established and the market can be used as an instrument to reach political goals, such as industrial growth and development (Asher 1997). A study by Ayub \& Hegstad (1987) of 13 countries concludes that rates of financial returns for state enterprises are relatively low and tend to be lower than for private enterprises, but there are also radical differences in financial returns among state enterprises within a country. However, a review of 28 studies on the comparative performance of state and private enterprises stresses the importance of market structure as opposed to ownership in the explanation of enterprise performance (Yarrow 1986, Chang 2003). Chang (2003) makes the point that managers and workers need incentives to perform well and that the soft budget constraint thus needs to be hardened. He also raises the issue of 'over-manning' in state enterprises and holds that workers should not have quasi property rights to a job, but protection from unemployment and deprivation. Regulatory framework and other institutional conditions must be taken into consideration in order to explain the performance of enterprises (Salazar-Xirinachs 1993, Peng 2000, Chang 2003). In Taiwan, for instance, state enterprises accounted for as much as one-third of fixed capital formation in 1950 to 1975 . This was a period of impressive economic growth and progress in industrialization. The corresponding share in South Korea exceeded 30\% in the early 1960s and 20\% in the 1970s (Wade 1990, Chang 2003). However, unlike centrally planned socialist economies, the two countries represent pragmatic cases of managed economies (Salazar-Xirinachs 1993). Strategic targeting by the state through an elaborate system of regulations and incentives has been essential to industrial upgrading in the two countries and private enterprises have also been subject to state intervention and facilitation 
(Lall 1996). The textile and garment industry has mainly been in private hands in Taiwan and South Korea. However, in Taiwan 'state enterprises accounted for a large part of investment in synthetic fibres' (Wade 1990, 110). In both countries the state created a competitive advantage in the industry through preferential access to long-term credit, low interest rates and tax credits, but there was no protection of workers. In South Korea the garment industry was a major source of foreign exchange, employment and economic growth, but at the same time state subsidies amounted to $27 \%$ of the value of garment exports in 1972 . According to Lee \& Song $(1994,148)$, 'this indicates that garment exporting has not been profitable in the normal sense; instead, government subsidies have compensated for losses and have maintained a minimum level of profit for garment manufacturers.' Over time, both South Korea and Taiwan have managed to upgrade their textile and garment industry to higher value products. Establishment of a high quality synthetic fibre and textile industry was important to the growth of the export-oriented garment industry (Gereffi \& Pan 1994, Gereffi 1996).

\section{Global competition in the textile and garment industry}

A system of global buyer-driven networks started to develop in the textile and garment industry in the 1970s. This means that lead firms, i.e. retailers, designers and trading companies, mainly in the western industrial countries, control and coordinate offshore production networks for labour-intensive consumer goods. In the late 1970s and 1980s enterprises from Hong Kong, Taiwan and South Korea became regional coordinators in Asia on behalf of the lead firms (Gereffi 1996). Lead firms and their regional coordinators are referred to as buyers. In Vietnam, as in other developing countries, the most common presence of foreign enterprises in the industry is in the form of buying-offices of the lead firms and their coordinators (interviews 2002). Global competition in the textile and garment industry is keen. The industry is labour-intensive, has low barriers to entry and suffers from market saturation. In order for buyers to reduce costs and enhance sales, inventories have to be small and there are 6-8 fashion seasons a year. This means that buyers in addition to low price also demand shorter delivery times and accountability in terms of delivery time and product quality. International trade in the textile and garment industry is signified by a system of quota trade. Selective quantitative measures by Europe and the USA to protect their domestic industry from cheaper imports in the 1960s eventually resulted in the first MultiFibre Arrangement (MFA), which was effective from 1974. In 1995 it was decided to abolish the quota trade for all members of the World Trade Organization (WTO) by the end of 2004 (Srinivasan 1996). The phase-out of the quota system intensifies competition in price, but low prices have to be combined with good quality products and shorter delivery times. Vietnam is first and foremost known for competitiveness in prices. Currently China offers the most serious competition to exports from Vietnam, and China and India are expected to become the leading exporters among the developing countries when the quota system is abolished. In addition to low costs of production, the two countries have the advantage of an integrated fibre, textile and garment industry, which is important in order to compete with a shorter delivery time. The garment industry in Vietnam still lacks backward linkages to an internationally competitive fibre and textile industry, and net export earnings range from negligible to negative (Vietnam Economic Times 1999-2000, GSO 2000a, Ham Pham Quang 2000, Hill 2000). Moreover, unlike China and India, Vietnam is not yet a member of the WTO and will continue to suffer from quota restrictions when other countries are exempted. Negotiations for accession have started, but are not likely to be completed by 2005 . 


\section{The economic transition in Vietnam}

In the 1970s state enterprises of high priority received the capital they needed from the Government, irrespective of their profitability. The objective was to protect jobs and the Government provided state enterprises with raw materials and labour. By the early 1980s a general shortage of consumer goods had developed, and as a result state enterprises that had attained the production targets of the Government were permitted to make extra products, sell them in the market and retain the profits (No"rlund 1996, Harvie \& Tran Van Hoa 1997). With the promulgation of doi moi in 1986, industrial policies shifted focus from heavy to light industries and the Government introduced profit-based accounting, eliminated centrally planned production targets and reduced its subsidies to state enterprises (CIEM 1997). In the resolution of the Fourth Conference of Vietnam's Communist Party (12/1987), it was recognized that private enterprises play a positive role in economic development. The Law on Foreign Investment of 1987 opened most sectors of the economy to foreign direct investment, and incentives were provided in order to promote exports and to earn hard currency (Harvie \& Tran Van Hoa 1997). The system of direct government subsidies to the state enterprises was terminated by 1992. State employees no longer received subsidized food and consumer goods, but wages were increased (No“rlund 1997). From 1988 to 1992 closures and mergers reduced the number of state enterprises considerably. In 1992 the Government decided to promote equitization of state enterprises. Equitization turns the enterprises into joint stock companies in which the state, workers and private investors hold shares. It is either the state or the private investors who hold the majority shares (Kokko \& Sjo"holm 2000). Equitization has proceeded slowly due to resistance from the managers and fear of job losses. In 1994 the Ministry of Industry established Vinatex as a unity of all centrally state-run enterprises in the textile and garment industry. By June 2002, only seven Vinatex units had been equitized and they still belonged to Vinatex (interview 2002). The Government plans to restrict the role of state enterprises to key sectors of the economy by 2010, but presently there are no signs that the textile and garment industry will be privatized collectively (Vietnam News 2002).

\section{Performance of the textile and garment industry}

It is important to note that the present growth in production and exports of the textile and garment industry is not solely a post-doi moi phenomenon. The industry was growing steadily from 1975 throughout the 1990s. Already in the 1970s exports amounted to 70-80 million USD. Before 1990, the market in Eastern Europe and the former Soviet Union absorbed 95\% of the exports of textile and garments by value (GSO 1976-1999, Tran Ngoc Ca 1999). When this market collapsed, Vietnam had to search for new opportunities and the industry was included in global networks. In 1992, a trade agreement was signed with the European Community (EC), which opened a quota-regulated export market for the textile and garment industry. At the same time, Norway and Canada also granted export quotas, and exports were diversified to non-quota markets in Japan, Taiwan, and the Association of Southeast Asian Nations (ASEAN). The bilateral trade agreement with the USA, effective from December 2001, has turned the USA almost from scratch to become the single largest market for textiles and garments from Vietnam. In 2002, 30\% of the exports went to the USA, 20\% to the EU and 18\% to Japan. Exports to the EU and Japan dropped both as shares of the total and in absolute figures (Vietnam News 2003). In 2000 the textile industry in Vietnam accounted for $61 \%$ of the output of the textile and garment industry by value. Regarding exports, however, the garment industry is the larger. It contributes as much as 77\% of the value and has largely retained the same share since 1985 (Hill 1998, VITAS 2002). In global networks of the textile and garment industry high quality fabrics are usually sourced from western industrial countries, South Korea and Taiwan. China is an important 
source of good quality and less expensive fabrics. The share of the state sector in the textile and garment industry peaked in 1989 when it accounted for $70 \%$ of the gross output (GSO 1976-1999, 2000c, 2001). In 1999 it accounted for only 42\% of gross output, as opposed to $30 \%$ by the non-state sector and $29 \%$ by the foreign sector (based on GSO 2000b). It is evident that the change in government policy has reduced the significance of the state sector in the textile and garment industry, although it is still the largest of the three sectors in the textile industry, accounting for $48 \%$ of the gross output. In comparison, the non-state sector accounts for $22 \%$ and the foreign sector for $31 \%$. In the garment industry, which is less technology-intensive than the textile industry, the non-state sector has become the largest single sector, accounting for $44 \%$ of the gross output. The state sector accounts for $31 \%$ and the foreign sector for $25 \%$ of the gross output (GSO 2000b). In national statistics the non-state sector refers to both the private Vietnamese sector and the cooperative sector. This is because the cooperative sector has more in common with the private sector than the state sector. The non-state sector consists predominantly of private Vietnamese enterprises. National statistics on exports of textiles and garments according to ownership are only available for 1992-1997 and for the garment sector. The share of state enterprises declined from 83\% in 1992 to 58\% in 1997, but they still dominate garment exports. The share of private Vietnamese enterprises increased from $18 \%$ to $26 \%$. The share of foreign enterprises rose from $0 \%$ to $17 \%$ (MPDF 2000). The export value of garments of all of the three ownership categories increased in this period. One should keep in mind that, because it is illegal to sell export quotas, export quota production that has been sold by state enterprises to private Vietnamese enterprises is counted both as output and exports of state enterprises. Hence, figures on output and exports of garments by state enterprises are overestimated in Vietnamese statistics.

\section{Preferential treatment of state enterprises}

\section{Land policy}

The principle of the land policy is that land belongs to the people, represented by the Government. The Land Law of 1993 and its decrees regulate the rights to sell, lease, inherit and mortgage land-use rights. There are two types of landuse rights, long-term rights and rental leases. Only state enterprises, households and individuals could obtain longterm landuse rights (Nguyen Tuan Dung 1996). In 1995 it was decided that all land-use rights on commercial properties should be transferred into rental leases (Pham Van Thuyet, unpublished data). Land-use rights of private Vietnamese and foreign enterprises cannot be used for other than the licensed purposes. This rigidity reduces the flexibility of the enterprises because they cannot follow market signals and shift to other business activities. Transfer of land-use rights are subject to government approval on a case-by-case basis. Hence, it is also difficult for private Vietnamese and foreign enterprises to acquire land for industrial sites in the first place. The process of land acquisition takes several years of negotiation and is thus very costly. Even when access to land is obtained, it is valid only for a limited period of time (CIE 1998, Hill 1998, World Bank 1999, MPDF 2001). The manager of one of the private Vietnamese enterprises explained that they lease land from the local government, and why the process of land lease is very costly and time consuming. First, they had to obtain approval for their investment project from the Department of Planning and Investment, the Department of Construction and the Department of Environment and Natural Resources. Second, their land lease proposal had to be submitted to the Department of Land Administration, and third, it had to be approved by the chairman or vice chairman of People's Committee. When the enterprise wanted to set up a textile factory in 1996 it took six months to get through these steps and another seven months to construct the factory. According to the manager, bureaucratic procedures are clear, but rent-seeking bureaucrats 
delay the process. In 1995 the same enterprise had to tear down a factory that it had just received approval to construct because the building was not in accordance with local regulations on architecture: 'Nobody informed me about the regulations when I submitted my project' (interview 2000). However, with support from a high-ranking official of the local government, he was later able to reconstruct the factory. With the new Enterprise Law of 2000, proposals are only submitted to the Department of Planning and Investment, which coordinates the rest of the process. However, the manager still claims that the Department of Land and Administration delays the issue of land lease certificates and that it is necessary to pay to get out of such deadlocks (interview 2000).

In contrast to private Vietnamese and foreign enterprises, land was initially assigned to state enterprises free of charge. This changed in 1995 when the system of rental leases was introduced. Nevertheless, private Vietnamese enterprises and foreign enterprises pay more for the use of land than state enterprises (Table 1). The survey data also reveals that the average area of land used by the state enterprises in 1998 was 77,800 m2, compared with 43,500 m2 used by foreign enterprises and only $4600 \mathrm{~m} 2$ by private enterprises. The respective average annual turnover of the three categories of enterprises in the sample is 58.2 billion VND, 95.5 billion VND and 6.6 billion VND (in 1998 USD 1 equalled VND 13,900). The high turnover and small size of land of the foreign enterprises compared with the state enterprises is indicative of preferential treatment of the state enterprises. It has been easier for state enterprises to get access to land and they also pay less for it. The more capital-intensive production that characterizes the foreign enterprises in general does not significantly reduce the requirement for space.

Table 1. Land rent according to ownership 1997-1998. ${ }^{1}$

\begin{tabular}{llll}
\hline Land-rent rate & Median & Mean & Standard Deviation \\
\hline State enterprises & 0.004 & 0.006 & 0.006 \\
Private enterprises & 0.020 & 0.021 & 0.022 \\
Foreign enterprises & 0.027 & 0.024 & 0.014 \\
\hline
\end{tabular}

\footnotetext{
${ }^{1}$ Average of the two years. The difference between the median of the state enterprises and the private Vietnamese enterprises on the one hand and the median of the state enterprises and the foreign enterprises on the other hand are both statistically significant at $5 \%$ level of significance by the Wilcoxson rank-sum test. The formula for calculating the land-rent rate is $L R^{*} 100 / L A$, where $L R$ is the yearly land rent payment in Vietnamese dongs; $\mathrm{LA}$ is the leased land area by $\mathrm{m}^{2}$

Source: Survey data.
}

\section{Credit policy}

Foreign enterprises included in the survey did not take loans from the domestic banking system and did not report any difficulties in access to credit from the international finance market. However, when land and buildings in Vietnam are only rented, loans are difficult to obtain internationally for some of the smaller foreign enterprises (interview 2002). The survey data reveal considerably higher rejection rates for both long-term and short-term bank loans to private Vietnamese enterprises than to state enterprises. While $50 \%$ of the applications for long-term loans by private Vietnamese enterprises in the survey were rejected, only $7 \%$ of the applications by the state enterprises were rejected. The respective rejection rates for short-term loans were $54 \%$ and $2 \%$. At the same time, the credit structure for state enterprises is riskier than for private Vietnamese enterprises, measured by the debtequity ratio. The debt-equity ratio of the state enterprises was 1.22 in 1998, i.e. exceeding the size of their equity. In comparison, the debt-equity ratio of the private Vietnamese enterprises 
was 0.67 and the foreign enterprises was 0.36 . The survey data do not reveal any difference in the interest rate on loans taken by state enterprises and private Vietnamese enterprises. This applies both to short-term and long-term loans (Table 2).

According to the survey data, the bulk of available credit was directed to state enterprises. This is not surprising, taking into consideration that in 1997 the Government announced that strict adherence to collateral requirements should not be practised vis-à-vis state enterprises (Kokko \& Sjöholm 2000). In contrast, private Vietnamese enterprises were required to raise high levels of collateral, which is difficult to obtain in a context of scarce capital resources. A private Vietnamese enterprise was set up with the owners' money in 1988. In order to keep up with growing demand, it needed a long-term loan in the 1990s to expand its production facilities. However, it was only possible to obtain short-term loans. It took the enterprise six months get such a short-term loan of 3 billion VND in 1999. This was the first time since inception that they succeeded in attaining a loan.

Table 2. Short-term and long-term interest rates according to ownership 1997-1998. ${ }^{1}$

\begin{tabular}{lccl}
\hline & Median & Mean & Standard Deviation \\
\hline Short-term interest rate & $(\%)^{2}$ & & \\
State enterprises & 1.105 & 0.800 & 0.500 \\
Private enterprises & 1.200 & 0.900 & 0.900 \\
Long-term interest rate & $(\%)^{3}$ & & \\
State enterprises & 0.701 & 0.811 & 0.347 \\
Private enterprises & 0.592 & 0.896 & 0.345 \\
\hline
\end{tabular}

\footnotetext{
${ }^{1}$ Foreign enterprises did not take short-term or long-term loans.

${ }^{2}$ The formula for calculating the short-term interest rate: SIR*100/SRL, where SIR is the monthly short-term interest payment and SRL is the short-term loan or loan with a borrowing period of less than one year. Payment is in Vietnamese dongs (VND).

${ }^{3}$ The formula for calculating the long-term interest rate: LIR*100/LRL, where LIR is the monthly long-term interest payment and LRL is the longterm loan or loan with a borrowing period of more than one year. Payment is in Vietnamese dongs.

Source: Survey data.
}

As in the case of land lease, the process is cumbersome. First they have to identify the right bank. Then, in order to approach representatives of the bank informally, 'of course you must spend time and money' (interview 2000). When the bank manager is convinced, they have to work with lower level bank managers who are sent to investigate the factory and production. Finally, they have to approach the local government to get the necessary political back-up, as the local government can influence the decision of the bank: 'This step is the most challenging barrier to my company. It is costly and time-consuming' (interview 2000). Over time, private enterprises have become more socially accepted and some of them have grown and attained a good footing in the market. The qualitative interviews in private enterprises in 2002 revealed that some of the bigger private Vietnamese enterprises have access to bank loans and do not find it particularly difficult to get these. This also applies to other private Vietnamese enterprises where the owners have close political contacts. A system has recently been introduced where sale contracts can be mortgaged and serve as a guarantee, 
but commercial banks are reluctant to apply it. They fear that customers of the enterprises will delay or will not repay the loan on time (Vietnam Investment Review 2002). The option to mortgage land-use rights and use these as collateral for bank loans has only been possible for state enterprises (Pham Van Thuyet, unpublished data). However, at the Party Plenum in 2001, it was stated that private enterprises too have the right to do so (World Bank 2002). In practice it is a problem for private Vietnamese enterprises to document their land-use rights, but this may improve when the National Register Agency for Secured Transactions becomes operational. In the light of the findings on access to credit, it is not surprising that the state enterprises are more capital-intensive than the private Vietnamese enterprises, both in the textile industry and the garment industry (Table 3). The state enterprises are also more involved in manufacture of textiles, which requires more advanced technology than the garment sector. Nevertheless it is 'an established fact' among industry representatives that enterprises in the state sector employ more workers than they require which in turn affects their profitability negatively. When in-depth interviews were made in a loss-making and a profitable state enterprise in 2000, the managers of both enterprises claimed that labour redundancy exceeds $10 \%$ of the workforce. This is a sensitive issue, so even at this level it may have been underreported. In fact, results of regression analyses of average labour redundancy in the textile and garment industry in Vietnam vary from $17 \%$ to $65 \%$ of the workforce, depending on the model applied (Belser \& Rama 2001). The manager in the lossmaking enterprise argued that a large number of workers is an advantage in negotiations for long-term credit. He had obtained credit to invest in production facilities and increase the labour force further. The enterprise suffered from a risky capital structure, financial loss for consecutive years and had difficulties in selling their products in the free market, but the Government also intervened at a later stage and bought $40 \%$ of their output. Moreover, workers elect managers. This means that the position of the manager could be threatened if he acts against the interests of the workers. For example, a manager who dismissed 100 workers in 1993 had to resign following the next election in 1996. Workers may also use their power in the party and the union at the enterprise level and block political promotion of their manager (interviews 2000).

Table 3. Employment according to ownership 1998.

\begin{tabular}{|c|c|c|c|c|}
\hline & \multirow[b]{2}{*}{ Units } & \multicolumn{3}{|c|}{ Ownership } \\
\hline & & State & Private & Foreign \\
\hline \multicolumn{5}{|l|}{ Textile sector } \\
\hline Employment & Persons & 74,708 & 97,199 & 19,354 \\
\hline Employment share & $\%$ & 39.1 & 50.8 & 10.1 \\
\hline Capital intensity & mill. VND per person & 75.0 & 37.3 & 201.2 \\
\hline \multicolumn{5}{|l|}{ Garment sector } \\
\hline Employment & Persons & 83,537 & 167,680 & 32,932 \\
\hline Employment share & $\%$ & 29.4 & 59.0 & 11.6 \\
\hline Capital intensity & mill. VND per person & 11.7 & 2.7 & 88.8 \\
\hline
\end{tabular}

* Capital intensity is measured by the ratio of total capital over total labour.

Source: GSO 2000a.

\section{Allocation of export quotas}

In Vietnam the Ministry of Trade allocated the export quotas until 1998. Private Vietnamese enterprises could apply for export quotas, but the procedures were difficult and costly and the outcome was meagre. Resale or transfer of export quotas from state enterprises to private enterprises is illegal. It is, however, well known that state enterprises sell export quotas to 
private Vietnamese enterprises. It is by such indirect export quotas that private enterprises usually get access to the market in the European Union (EU). The survey data confirm that it is difficult for private Vietnamese enterprises to get direct access to the export quotas. As much as $88 \%$ of the state enterprises exported by direct export quotas in 1997-1998, as opposed to $40 \%$ of the private Vietnamese and 54\% of the foreign enterprises. Quota fees amounted to $2.2 \%$ of the cost of production in state enterprises, $3.3 \%$ in private Vietnamese enterprises and 5.6\% in foreign enterprises. To ease the system of quota allocations, auctioning of export quotas to the highest bidders started in 1999. That year, 25\% of the quotas were auctioned. While $44 \%$ of the bidders were private enterprises, only $26 \%$ of them obtained such quotas (World Bank 1999). Neither of the two private Vietnamese enterprises interviewed in 2000 obtained export quotas. One of them avoided the problem by directing exports to South Korea. The other enterprise depends on a social network of relatives and has targeted the Polish market. In an interview with yet another private Vietnamese enterprise in 2002 it was mentioned that it is possible to gain access to the German market via Poland. Hence, the above decline in demand from quota-free markets and the fact that a number of Eastern European countries, such as Poland, have been included in the EU as from May 2004, increases the problems of market access for private Vietnamese enterprises that are not willing to buy export quotas illicitly. A manager of a successful private Vietnamese enterprise said in 2002: 'we are successful because we are invisible to the Government'. Illicit quota trade could make them visible and cause trouble. In May 2001 an automatic system of quota allocation was introduced. Automatic in this respect means that quotas are allocated on a 'first come, first served' basis and the enterprises may submit their application for the quotas on the Internet. An anonymous high-ranking official in the industry confirmed that it is still very difficult for private Vietnamese enterprises to get access to quotas and that they still have to buy quotas from the state enterprises. One of the equitized state enterprises claims to pay 2-3 times more for the quotas than the normal price. In the foreign enterprises, they answered that they do not really have problems in getting the quotas they need, but it was also held that the process is 'a hassle' (interviews 2002). In sum, the survey data confirm preferential treatment of state enterprises. Private Vietnamese and foreign enterprises are at a disadvantage compared with state enterprises regarding the difficult process of getting access to land, and private Vietnamese and foreign enterprises have to pay higher land rents than state enterprises. Private Vietnamese enterprises are also at a disadvantage compared with state enterprises in terms of access to credit. One reason for this is that they cannot use land as collateral. It is evident that performance criteria have played a limited role in the allocation of credit. Most of the bank loans go to state enterprises, although these have a riskier capital structure than the private Vietnamese enterprises. Despite the fact that it has recently become somewhat easier for private Vietnamese enterprises to obtain bank loans, the problem of raising collateral that the banks will accept in practice still remains. The survey data also confirm that private Vietnamese enterprises and foreign enterprises suffer discrimination in allocation of export quotas.

\section{Preferential treatment and profits}

Operating profit to capital, i.e. total assets, indicates how efficiently an enterprise uses its capital resources. The survey data show that state enterprises are more profitable than private Vietnamese enterprises in this respect, both before and after adjustments are made for preferential treatment of state enterprises in terms of export quota fees and land rent (Table 4). Despite the increase in profit that private Vietnamese enterprises attain after adjustment, the difference in performance between state enterprises and private Vietnamese enterprises is still statistically significant. It is not surprising as such that state enterprises attain higher profits than the private Vietnamese enterprises in a transition context where it takes time and a lot of 
resources for private enterprises to establish.

Table 4. Profit ratios in state enterprises and private Vietnamese enterprises 1997-1998.

\begin{tabular}{|c|c|c|c|c|c|c|}
\hline & \multicolumn{3}{|c|}{ Operating profit to capital (\%) } & \multicolumn{3}{|c|}{ Net operating profit to sale (\%) } \\
\hline & median & mean & std dev. & median & mean & std. dev. \\
\hline State & 15.4 & 15.7 & 8.9 & 0.9 & 1.0 & 5.2 \\
\hline Priv. Viet. & 8.2 & 9.7 & 9.8 & 0.6 & 0.1 & 5.7 \\
\hline Difference & $72^{\circ}$ & 6.0 & & & & \\
\hline \multicolumn{7}{|l|}{ Adjusted" } \\
\hline State & 15.4 & 15.7 & 8.9 & 0.9 & 1.0 & 5.2 \\
\hline Priv. Viet. & 9.4 & 11.2 & 0.1 & 2.2 & 2.0 & 69 \\
\hline Difference & $6.0^{\circ}$ & 4.5 & & -1.3 & -1.0 & \\
\hline
\end{tabular}

- The difference is statistically significant at $1 \%$ by the Wilcoxson rank-sum test.

* Adjusted means that profits of the private Vietnamese eaterprises are adjusted to what they would have been if the private Vietnamese enterprises paid the same quota fees and same level of land rent as the state enterprises.

Soturce: Caleulations by Cuong Manh Nguyen based on survey data.

Regarding net operating profit to sale, private Vietnamese enterprises do slightly better than state enterprises after the adjustment is made, although the difference is not statistically significant. The finding implies that the choice of output of state enterprises is not more efficient than the choice of private Vietnamese enterprises.

\section{Preferential treatment and contribution to industrial growth}

The previous dominance of state enterprises in the output of the textile and garment industry is declining and the private Vietnamese sector is dynamic despite preferential treatment in favour of state enterprises. In contrast to the neoliberal notion that preferential treatment of the state sector undermines the private sector, it makes more sense to hold that preferential treatment of weak state enterprises slows further development of successful private Vietnamese enterprises. There are private enterprises that experience growing demand but are unable to access credit and quotas, yet at the same time state enterprises with a risky capital structure are able to access loans. Preferential treatment is not only given to well-managed or profitable state enterprises to boost their growth, but also to save weak state enterprises from bankruptcy. Weak enterprises are those with a risky capital structure and general difficulties in selling their products in the free market over consecutive years. In other words, preferential treatment has not been applied as an industrial strategy to earmark and support (potential) winners in the market, as in the case of South Korea and Taiwan. An important factor that explains access to preferential treatment by weak state enterprises in Vietnam is that a more tacit aim of employment supplements the publicly stated objective of business for profits. In the same vein, privatization and equitization have proceeded slowly because of fear that reduction of over-manning will lead to high levels of unemployment that, in turn, may lead to social instability. To put this into perspective, Belser \& Rama (2001) conclude that c. $25 \%$ of the workers in the state sector in Vietnam will lose their jobs as a result of the reform rogramme.

Foreign manufacturers do not usually have to compete with state enterprises for capital and they are superior in terms of technology. The disadvantage that the wholly foreign-owned enterprises may suffer in terms of the quota system is temporary, given Vietnam's accession to the WTO. In addition, foreign enterprises have a close relationship with buyers in the export markets, which is an essential factor in order to be able to survive after 2004. In spite of the fact that foreign manufacturers often find that the bureaucracy in Vietnam is difficult to deal with, the same bureaucracy protects them once they have a good personal network in place (interview 2002). Hence, in sum, they do not suffer from preferential treatment of state enterprises to the same degree as private Vietnamese enterprises. On the contrary, foreign 
manufacturers in joint ventures with state enterprises benefit from the preferential treatment of their partner. Foreign buyers also make a point that they do not directly deal with the problems of access to land, capital and export quotas. They select suppliers among the state enterprises and private enterprises who provide products with the right combination of price and quality and already have the required machinery in place (Knutsen 2003). From the angle of buyers and their requirements, state enterprises in Vietnam are not generally perceived as inefficient, but rather as fairly attractive business partners. The fact that state enterprises enjoy preferential treatment does not automatically infer that all state enterprises are bureaucratic, employ obsolete technology and manufacture inefficiently. The state sector in Vietnam is not as weak as one may expect in light of neoliberal theoretical arguments in favour of fast privatization. It is a case in point that both big and small foreign buyers that were interviewed in 2002 tend to prefer collaboration with state enterprises. This is not only a matter of access to export quotas. Smaller buyers complain that big buyers for the US market squeeze them out of the state enterprises. The large volumes of garments that state enterprises can supply are important to the nature of demand in the US market, which has just become the largest market for exports of garments from Vietnam, and explains the continued growth of the industry over the past few years. In addition, buyers consider state enterprises more professionally managed and more reliable in terms of delivery than many of the private Vietnamese enterprises. According to buyers, state enterprises also have more advanced technology in place. The relatively good performance regarding operating profit to capital in the sample of state enterprises may corroborate this (Table 4). The close link to the state is considered an advantage: if there is a problem, 'we contact the Ministry and the problem is solved' (interview 2002). With private companies they have to go to court, which is a long and difficult process. This contrasts to the notion that privatization is crucial to global competitiveness and important in terms of 'the explosion in demands for greater accountability’ (Zahra \& Hansen 2000, 1, italics added). In the case of Vietnam the close link to the state is both perceived as and experienced as a guarantee of accountability and flexibility. This is important in a transition context when manufacturers either have not been exposed to the market economy before at all or have been disassociated for several years. In a number of private Vietnamese enterprises it was stressed that they need more competence on competition and marketing in the global market (interviews 2002). The strategy of a successful and profitable private Vietnamese enterprise (interview 2000) is to increase the use of home workers because they only earn a third of the earnings of permanent workers. Increasingly stronger focus by the general public on the ethical behaviour of buyers to some extent favours state enterprises. This is because they pay better and have a better reputation regarding working conditions than private Vietnamese enterprises (interviews 2002). It is costly to upgrade facilities both to the companyspecific codes of conduct that buyers may demand and even more so to attain international certifications such as ISO 140002 and SA 80003. In this respect, state enterprises have both the advantage of economies of scale and better access to capital than private Vietnamese enterprises. US buyers especially are concerned with ethical standards. Keen global competition in price leads to subcontracting from state enterprises to private Vietnamese enterprises to home industry units (Tran 1997, interviews 2002). However, to some buyers a good reputation or good working conditions on paper suffice, and buyers do not usually follow up the subcontractors of their manufacturing suppliers. Preferential treatment over time has facilitated large-scale production and upgrading of technology in state enterprises. Moreover, access to export quotas and capital as well as more detailed information from the Government partly explain why state enterprises can plan better and act more professionally vis-à-vis buyers than many private Vietnamese enterprises (interviews 2002). This also implies that state enterprises in the present context have a role to play in growth in the industry and as spearheads of access to 
foreign markets. How conducive this growth is to the Vietnamese economy in the longer run is another question. Preferential treatment of state enterprises means that the state indirectly subsidizes foreign buyers. Most of the manufacturers that were interviewed in 2002 complained that buyers constantly pressure for lower prices and that cost-price margins decline. To the extent that this eventually prevents reinvestment in technology, competitiveness in the longer run will be severely affected. The problem of declining costprice margins has to do with market saturation, keen South-South competition for access to markets in the North and the power of lead firms in the buyer-driven networks to take advantage of the latter. This is a phenomenon that also affects exporters of garments in other countries, such as Sri Lanka and Turkey (Knutsen in press, interviews in Turkey 2003). A local supply base of internationally competitive textiles is important to support the competitiveness of the garment industry in the longer run. This is especially important for upgrading to higher quality products for higher income market segments. Reduction of delivery times requires backward linkages in close geographic proximity. Because pricecompetition in the industry is keen and profits levels low, there is often little interest by private manufacturers to invest in the fibre and textile sector, even in countries where the industry is in private hands. Hence, as in the case of Taiwan, state enterprises may have an important role to play in the development of a competitive fibre and textile sector, a process that Vinatex has started. In this respect the state sector can be said to undertake a role that is not attractive to the private sector. Private Vietnamese enterprises survive and grow in the market and are thus surprisingly robust in light of the bias they suffer due to preferential treatment of state enterprises. Close ties to the state or connections with the political elite characterize some of the private Vietnamese enterprises that performed well and reported few problems in access to land, credit and quotas in 2002. This is consistent with the point made by Luong (2001) that successful private Vietnamese enterprises depend on an elaborate system of personalized relationships, which ensures that they get the inputs and certifications they need and that they get them in time. Even for state enterprises to attain preferential treatment, much depends on personal networking as they compete with each other for support from the state (interviews 2002). In the longer run such relationships require large resources in terms of time and gifts that could better be spent on technology upgrading (Peng 2000). Two state enterprises that were interviewed in 2000 reported that an amount equal to $5 \%$ of the value of their total sales is set aside to build relationships with business partners and bureaucrats, mainly the latter. Similar forms of networking were also confirmed among foreign enterprises. Hence, a level playing field in which possible support from the state is based on performance-related criteria may result in better resource utilization in the industry, as less would be required to maintain these personalized relationships. This represents a potential of improved quality and higher efficiency through technological change, required in order to sustain and enhance the share of the textile and garment industry in the global market.

\section{Concluding remarks}

A level playing field with state enterprises is not necessarily a sufficient condition for further development of the private sector. Among other factors that matter are entrepreneurial skills in general, as well as organizational skills and information and knowledge of international marketing. It takes time to develop an institutional framework that is conducive to growth and development of private Vietnamese enterprises. In addition to the more formal changes of the political and judicial type, it requires changes in socially sanctioned norms. At present, well-managed state enterprises have a role to play for market access abroad and thus for the growth of the industry, and this will remain so until the private sector is capable of meeting the demand. Increasing demand for production capacity in state enterprises also 
generates more interest in the private Vietnamese sector. This happens through subcontracting and the fact that buyers that are squeezed out of state enterprises start searching for wellmanaged private Vietnamese enterprises. This is in line with what the Deputy Prime Minister of Vietnam expressed in 2000, i.e. that the Government should support and invest in the wellmanaged state enterprises for these to lead the development of the textile and garment industry. Possibilities to increase exports with the opening of the US market also press for better business conditions for the private Vietnamese enterprises. The close link to the state is important in explaining how state enterprises can manage their business professionally and thus be attractive partners to the buyers. This is a dilemma in the transition to a more market-oriented economy, as the same link also tends to protect the weak among the state enterprises and slow the development of well-performing private Vietnamese enterprises. The present interest of the buyers in large and well-managed state enterprises reveals that the state has a role to play in the creation of a competitive advantage in the textile and garment industry as in South Korea and Taiwan. If there is not sufficient production capacity accessible of the type that satisfies the requirements of foreign buyers regarding quality of production and reliability, buyers may choose to source from other countries than Vietnam. However, access to preferential treatment based on personalized relations for personal gains rather than business performance represents a waste of resources. After all, it is the wellmanaged enterprises that buyers are in search of.

\section{Notes}

1 Cuong Manh Nguyen participated in this survey, which was sponsored by the Canadian International Development Research Centre between 1998 and 2000, and has permission to use the data. A team of interviewers were trained to collect the data. Cuong Manh Nguyen also undertook the qualitative interviews in 2000. The fieldwork in 2002 was done in connection with Knutsen's project on the garment industry in Vietnam (Knutsen 2003). In 2002, Knutsen undertook extended interviews in 21 manufacturing enterprises, five buying offices, three suppliers of inputs, and four industry associations. Cuong Manh Nguyen translated from Vietnamese to English.

2 ISO 14000 = International Organization for Standardization standards on environmental management.

3 SA 8000 = Social Accountability International's social accountability system for humane workplaces.

Manuscript submitted 2 December 2003; accepted 19 May 2004

\section{References}

Asher, M. 1997. Role of government and public-private sector mix: The ASEAN experience. Ng Chee Yuen, Freeman, N. \& Huynh F.H. (eds.) State-Owned Enterprise Reform in Vietnam. Lessons from Asia, 122-137. ISEAS, Singapore.

Ayub, M.A. \& Hegstad, S.O. 1987. Management of public industrial enterprises. The World Bank Research Observer 2, 79-101.

Belser, P. \& Rama, M. 2001. State ownership and labor redundancy. Policy Research Working Paper WPS 2599. The World Bank, Washington DC. 
Chang, Ha-Joon. 2003. Globalisation, Economic Development and the Role of the State. Zed Books, London and Third World Network, Penang.

CIE 1998. Policies for Industrial Development and Reform. Report submitted to the Ministry of Planning and Investment. Centre for International Economics, Sydney.

CIEM 1997. Report on the Situation of State Enterprises after the Ten Years of the Reform and Orientation of Continuing the State Enterprise Reform. Central Institute for Economic Management. National Political Publishers, Hanoi.

CIEM 2002. Vietnam's Economy in 2001. Central Institute for Economic Management. National Political Publishers, Hanoi.

Ellman, M. 1997. The political economy of transformation. Oxford Review of Economic Policy 13:2, 23-31.

Gereffi, G. 1996. The elusive last lap in the quest for developed-country status. Mittelman, J. (ed.) Globalization. Critical Reflections, 53-81. Lynne Rienner, London.

Gereffi, G. \& Pan, M.-L. 1994. The globalization of Taiwan's garment industry. Bonacich, E., Cheng, L., Chinchilla, N., Hamilton, N. \& Ong, P. (eds.) Global Production. The Apparel Industry in the Pacific Rim, 126-146. Temple University Press, Philadelphia.

Griffin, K. 1998. Restructuring and economic reforms. Griffin, K. (ed.) Economic Reform in Vietnam, 1-19. MacMillan, Basingstoke.

GSO 1976-1999. Statistical Yearbook [issues 1976-1998]. General Statistical Office. Statistical Publishing House, Hanoi.

GSO 2000a. Analysing the Results of the Industrial Survey in Vietnam 1999. General Statistical Office of Vietnam. Project VIE/97/051. Statistical Publishing House, Hanoi.

GSO 2000b. Statistical Data of Vietnam. Socio-Economy 1975-2000. General Statistical Office, Hanoi.

GSO 2000c. Statistical Yearbook 1999. General Statistical Office. Statistical Publishing House, Hanoi.

GSO 2001. Statistical Yearbook 2000. General Statistical Office. StatisticalPublishing House, Hanoi.

Ham Pham Quang, 2000. Vietnam’s Textile and Garment Industry Development. Research report. Vietnam-Japan Joint Research, Hanoi.

Harvie, C. \& Tran Van Hoa, 1997. Vietnam’s Reforms and Economic Growth. Routledge, Basingstoke.

Hill, H. 1998. Vietnam textile and garment industry: Notable achievements, future challenges. Industrial Competitiveness Review, Appendix II. Prepared for the Development Strategy Institute, Ministry of Planning and Investment, Vietnam and Medium-Term 
Industrial Strategy Project. United Nations Industrial Development Organization, Hanoi.

Hill, H. 2000. Export success against the odds: A Vietnamese case study. World Development 28:2, 283-300.

Johnson, S. \& Loveman, G. 1995. Starting Over in Eastern Europe. Harvard Business School Press, Massachusetts.

Knutsen, H.M. 2003. The Garment Industry - a Steppingstone of Industrialisation in Vietnam? Human Geography Occasional Paper No. 42. Department of Sociology and Human Geography, University of Oslo.

Knutsen, H.M. Industrial development in buyer-driven networks. The garment industry in Vietnam and Sri Lanka. Journal of Economic Geography. In press.

Kokko, A. \& Sjöholm, F. 2000. Some alternative scenarios for the role of the state in Vietnam. The Pacific Review 13:2, 257-277.

Kornai, J., Maskin, E. \& Roland, G. 2002. Understanding the Soft Budget Constraint. School of Social Science Paper 19. Institute for Advanced Study, Princeton.

Lall, S. 1996. Paradigms of development: The East-Asian debate. Oxford Development Studies 24:2, 111-131.

Lee, H.S. \& Song, H.K. 1994. The Korean garment industry: From authoritarian patriarchism to industrial paternalism. Bonacich, E., Cheng, L., Chinchilla, N., Hamilton, N. \& Ong, P. (eds.) Global Production. The Apparel Industry in the Pacific Rim, 147-162. Temple University Press, Philadelphia.

Luong, H.V. 2001. The strength of Vietnamese industrial fabric: Institutional mechanisms of firm competitiveness in the textile and garment industry. Journal of Asian Business $17: 1,17-44$.

MPDF 2000. Vietnam's Garment Industry: Moving Up the Value Chain. Private Sector Discussions 7 Mekong Development Project Facility, Hanoi.

MPDF 2001. Doing Business Under the New Enterprise Law. Private Sector Discussions 12. Mekong Development Project Facility, Hanoi.

Nguyen Tuan Dung, 1996. Foreign direct investment in Vietnam. Leung, S. (ed.) Vietnam Assessment. Creating a Sound Investment Climate, 69-89. Richmond, Surrey.

Nörlund, I. 1996. Vietnamese industry in transition: Changes in the textile sector. Gates, C.L., No“rlund, I. \& Vu Cao Dam (eds.) Vietnam in a Changing World, 125-150. Curzon Press, Surrey.

No“rlund, I. 1997. The labour market in Vietnam: Between state incorporation and autonomy. Dragsbaek Schmidt, J., Hersh, J. \& Fold, N. (eds.) Social Change in Southeast Asia, 155-181. Longman, Harlow. 
Peng, M. 2000. Business Strategies in Transition Economies. International Business series. Sage, London.

Salazar-Xirinachs, J.M. 1993. The role of the state and the market in economic development. Sunkel, O. (ed.) Development from Within. Toward a Neostructuralist Approach for Latin America, 361-395. Lynne Rienner Publishers, Boulder.

Srinivasan, T.N. 1996. The Uruguay Round and Asian developing economies. Quibria, M.G. \& Malcolm Dowling, J. (eds.) Current Issues in Economic Development. An Asian Perspective, 229-275. ADB \& Oxford University Press, Hong Kong.

Tran, A.N. 1997. Through the eye of the needle: Vietnamese textile and garment industries rejoining the global economy. Crossroads: An Interdisciplinary Journal of Southeast Asian Studies 10:2, 83-126.

Tran Ngoc Ca, 1999. Technological Capability and Learning in Firms. Ashgate, Aldershot.

Vietnam Economic Times 1999-2000. Summary of industrial statistics 1999-2000. Vietnam Economic Times, Hanoi.

Vietnam Investment Review 2002. Banking sector baulks at new mortgage loan model. 13-19 May.

Vietnam News 2002. Government widens net to catch more SOEs for reform. 29 April.

Vietnam News 2003. Challenges for Vietnam textile garments. 24 January.

Vinatrade USA 2004. Garments and Textiles. Vietnam Trade Office in the USA. http://www.vietnam-ustrade.org/Eng/garments_\&_textiles.htm

VITAS 2002. An Overview of the Vietnam Textile and Garment Industry. SÔ 11, No. 4. Hanoi and HCMC.

VNC 1995. Law on State Enterprise. Vietnam National Congress, Hanoi.

Wade, R. 1990. Governing the Market. Princeton University Press, Princeton.

Waterbury, J. 1993. Exposed to Innumerable Delusions. Public Enterprise and State Power in Egypt, India, Mexico, and Turkey. Cambridge University Press, Cambridge.

Wolff, P. 1999. Vietnam - the Incomplete Transformation. GDI Book Series, No.12. Frank Cass, London and German Development Institute, Berlin.

World Bank 1999. Vietnam Preparing for Take-Off? How Vietnam Can Participate Fully in the East Asian Recovery. The World Bank in Vietnam, Hanoi.

World Bank 2002. Vietnam Economic Monitor. Spring. The World Bank in Vietnam, Hanoi.

Yarrow, G. 1986. Privatization in theory and practice. Public Policy 3.

Zahra, S. \& Hansen, C.D. 2000. Privatization, entrepreneurship, and global competitiveness in the 21st century. Competitiveness Review 10:1, 83-103 